\title{
PENGEMBANGAN E-MODUL MEMBACA SISWA KELAS 3 SDN 029 PEKANBARU
}

\author{
Isra Syahputri ${ }^{1}$, Febrina Dafit ${ }^{1}$ \\ ${ }^{1}$ Universitas Islam Riau, Pekanbaru \\ *Corresponding Address: israsyahputri@student.uir.ac.id
}

Naskah diterima: 1 November 2021| Disetujui: 9 November 2021 | Diterbitkan: 16 November 2021

\begin{abstract}
This study aims to prioritize e-modules on theme 2 sub-theme 3 for third grade elementary school. This research is a development research using the ADDIE model. The data collected in this study are quantitative data and qualitative data. The methods used to collect data are: observation, interviews, and questionnaires. The subjects involved in this study were 2 design experts, 2 material experts and 2 linguists. The data analysis technique used is quantitative and qualitative descriptive data analysis techniques. The results showed that the validation of design experts obtained an average of $92.31 \%$ in the "Valid" category, material experts obtained an average of $87.49 \%$ in the "Valid" category, and linguists obtained an average of $82.04 \%$ with the category "Valid". So that the average value obtained from the development of this reading e-module is $87.28 \%$ with the "Valid" category. Then based on the analysis of the third grade teacher's response questionnaire to the reading e-module, he received a positive response which obtained an average of $92.83 \%$ which indicates the "Very Interesting" category. The analysis of the students' responses to the reading $e$ module in thematic learning received a positive response which obtained an average of $83.33 \%$ which indicated the "Very Interesting" category.
\end{abstract}

Keywords: Teaching materials, E-Modules, Thematic

Abstrak:Penelitian ini bertujuan untuk menguji kelayakan e-modul pada tema 2 subtema 3 kelas III SD. Penelitian ini merupakan penelitian pengembangan menggunakan model ADDIE. Data yang dikumpulkan dalam penelitian ini adalah data kuantitatif dan data kualitatif. Metode yang digunakan untuk mengumpulkan data yaitu observasi, wawancara, dan angket. Subjek yang terlibat dalam penelitian ini adalah 2 ahli desain, 2 ahli materi, dan 2 ahli bahasa. Teknik analisis data yang digunakan adalah deskriptif kuantitatif dan kualitatif. Hasil penelitian menunjukkan bahwa validasi ahli desain menperoleh rata-rata sebesar 92,31\% dengan kategori "Valid", ahli materi memperoleh rata-rata sebesar 87,49\% dengan kategori "Valid", dan ahli bahasa memperoleh rata-rata sebesar $82,04 \%$ dengan kategori "Valid", sehingga nilai rata-rata yang diperoleh dari pengembangan e-modul membaca ini sebesar $87,28 \%$ dengan kategori "Valid". Berdasarkan analisis dari angket respon guru kelas III terhadap e-modul membaca mendapatkan respon positif yang memperoleh rata-rata sebesar 92,83\% yang menunjukkan kategori "Sangat Menarik". Analisis dari angket respon peserta didik terhadap e-modul membaca pada pembelajaran tematik mendapatkan respon positif yang memperoleh rata-rata sebesar 83,33\% yang menunjukan kategori "Sangat Menarik".

Kata kunci: Bahan ajar, E-Modul, Tematik

2656-9779 (C) 2020 The Author(s).

Published by Lembaga Penerbitan dan Publikasi Ilmiah Program Pascasarjana IAI Sunan Giri Ponorogo. This is an open access article under the CC BY-SA 4.0 license. DOI: 10.37680/qalamuna.v13i2.1081 


\section{PENDAHULUAN}

Pendidikan sebagai salah satu investasi masa depan (Desyandri et al., 2019), sedangkan pendidikan menurut (Musfah, 2015) adalah usaha sadar untuk mengembangkan akhlak, keterampilan, dan pengetahuan anak dan pemuda di sekolah atau di rumah, agar hidup mereka bahagia dan bermanfaat bagi masyarakat dan bangsa. Menurut UU No. 20 Tahun 2003 tentang Sisdiknas dijelaskan bahwa pendidikan adalah usaha sadar dan terencana untuk mewujudkan suasana belajar dan proses pembelajaran agar peserta didik secara aktif mengembangkan potensi dirinya untuk memiliki kekuatan spiritual keagamaan, pengendalian diri, kepribadian, kecerdasan, akhlak mulia, serta keterampilan yang diperlukan dirinya, masyarakat, bangsa, dan negara.Pelaksanaan kegiatan pembelajaran tidak terlepas dari penggunaan bahan ajar.

Dalam kegiatan pembelajaran, bahan ajar merupakan hal penting bagi guru dan siswa. Guru akan mendapat kesulitan dalam meningkatkan kualitas pembelajarannya jika tanpa disertai bahan ajar yang lengkap. Begitu pun dengan siswa, tanpa bahan ajar siswa akan mendapat kesulitan dalam belajarnya, jika guru kurang jelas dan terlalu cepat dalam menjelaskan materi pembelajarannya hal ini akan menambah kesulitan guru dalam memahamkan siswa. Oleh karena itu, bahan ajar merupakan hal yang sangat penting untuk dikembangkan sebagai upaya meningkatkan kualitas pembelajaran (Setiawan \& Andika Sari, 2018). Selain itu, menurut Sudjana (dalam Lestari, 2017) bahan ajar berfungsi untuk guru menyampaikan materi kepada siswa sehingga tujuan dari pembelajaran tercapai. Tanpa menggunakan bahan ajar, proses pembelajaran akan kesulitan dilaksanakan.

Di era yang maju dan modern, kecanggihan teknologi menyebabkan pembelajaran yang awalnya berjalan satu arah, dimana guru dan siswa saling bertemu dan berkomunikasi di dalam kelas, dapat diimplementasikan melalui teknologi informasi seperti handphone, android, tablet, smartphone, dll (Rif'ati, 2015). Pada era saat ini, bahan ajar yang bisa dimanfaatkan melalui teknologi adalah modul elektronik atau e-modul. E-modul merupakan modul elektronik yang aksesnya dilakukan melalui alat elektronik seperti komputer, handphone, tablet. E-modul atau elektronik modul adalah modul dalam bentuk digital, yang terdiri dari teks, gambar, atau keduanya yang berisi materi elektronika digital disertai dengan simulasi yang dapat dan layak digunakan dalam pembelajaran. E-modul dinilai lebih inovatif karena menyajikan materi secara lengkap, apalagi saat ini siswa sering membuka handphone daripada buku (Herawati \& Muhtadi, 2018). Dengan e-modul siswa bisa menggunakan handphonenya untuk belajar. E-modul memiliki kelebihan yaitu dapat menyediakan informasi berupa gambar atau bahkan video, sehingga membuat siswa lebih semangat dalam belajar. E-modul juga berisi materi-materi yang bisa dibaca siswa dimanapun dan kapanpun. 
Menurut Rahman \& Haryanto membaca merupakan suatu hal yang kompleks, tidak hanya sekedar melafalkan tulisan, tetapi melibatkan aktivitas visual seperti menterjemahkan simbol tertulis ke dalam kata-kata lisan, dan proses berpikir untuk mengenal dan memahami makna kata. Tujuan utama membaca adalah untuk mencari dan memperoleh informasi mencakup isi dan memahami makna bacaan (Budiarti \& Haryanto, 2016). Menurut Wilson \& Gambrell membaca didefinisikan sebagai suatu proses yang melibatkan penafsiran kode dan pemahaman (Tristiantari \& Sumantri, 2016). Membaca merupakan satu alat pembelajaran yang efektif karena memberi kekuatan pada seorang murid untuk membuat keputusan yang tepat dalam meningkatkan proses pembelajaran dan pemikiran. Seorang pembaca dapat memahami dan menilai teks yang dibaca dengan mengaktifkan skema prosedur dan isi skema yang terdapat di dalam dirinya.Membaca adalah suatu proses yang dilakukan serta dipergunakan oleh pembaca untuk memperoleh pesan, yang hendak disampaikan oleh penulis melalui media kata-kata/bahasa tulis.Membaca adalah suatu proses yang dilakukan serta dipergunakan oleh pembaca untuk memperoleh pesan, yang henda disampaikan oleh penulis melalui media kata-kata/bahasa tulis. Suatu proses yang menuntut agar kelompok kata yang merupakan suatu kesatuan akan terlihat dalam suatu pandangan sekilas dan agar makna kata-kata secara individual akan dapat diketahui (Tarigan, 1983). Menurut Susanto, salah satu dunia pendidikan yang dihadapi saat ini adalah lemahnya pelaksanaan proses pembelajaran yang diterapkan oleh guru di sekolah (Suratmi et al., 2018).

Berdasarkan hasil prapenelitian dengan menggunakan metode wawancara yang dilakukan pada tanggal 15 Maret 2021 dengan guru wali kelas III di SDN 029 Pekanbaru yakni Ibu Dwi Amalia S.Pd., menyatakan dalam kegiatan belajar mengajar lewat daring, tugas-tugas lebih banyak diberikan melalui whatsapp. Melalui whatsapp guru sering mengirimkan video-video pembelajaran mengenai materi yang diajarkan sehingga siswa lebih fokus belajar melalui handphone daripada membaca buku-buku pelajaran yang dipinjamkan sekolah. Siswa juga lebih banyak membaca materi-materi pembelajaran melalui internet dihandphone. Guru juga menyatakan bahwa terdapat beberapa kesulitan yang dialami selama pembelajaran, apalagi pada masa pandemi covid-19 seperti ini. Selama masa pandemi beliau menggunakan bahan ajar. Bahan ajar yang digunakan beliau seperti bahan ajar cetak dan non cetak.Dalam proses pembelajaran bahan ajar yang digunakan beliau adalah dalam bentuk video. Selama proses pembelajaran terdapat beberapa kesulitan yang dialami oleh guru, yaitu 1) Dalam proses belajar berlangsung terbatasnya cara guru menerangkan, 2) Video yang dibuat kurang bervariasi sehingga siswa kurang tertarik, 3) Sekolah kurang memadai sarana dan prasarana.

Berdasarkan permasalahan yang telah diuraikan, peneliti mencoba untuk memberikan solusi alternatif untuk menyelesaikan masalah tersebut dengan melakukan pengembangan bahan ajar berupa 
e-modul tematik. Dengan demikian, maka peneliti mengambil judul penelitian "Pengembangan EModul Membaca Siswa Kelas 3 SDN 029 Pekanbaru”.

\section{METODE}

Jenis penelitian yang akan digunakan peneliti adalah penelitian dan pengembangan (Research and Development). Penelitian pengembangan merupakan upaya untuk mengembangkan ilmu pengetahuan dan mendapat temuan-temuan yang baru (Hanafi, 2017). Penelitian dan pengembangan akan menghasilkan produk berupa bahan ajar berupa e-modul tematik untuk kegiatan membaca siswa.

Dalam mengembangan e-modul, peneliti menggunakan model ADDIE. Menurut Putramodel desain pembelajaran yang sifatnya lebih generik yaitu model ADDIE (Analysis-Design-DelevopImplement-Evaluate).Tahapan model ADDIE untuk mengembangkan e-modul ini dimodifikasi menjadi empat tahapan yaitu analisis, design, development dan implementasi (Qondias et al., 2016). Lokasi penelitian ini dilaksanakan di SDN 29 Pekanbaru, Jalan Harapan Raya. Kota Pekanbaru, Provinsi Riau. Angket kebutuhan dalam pengembangan produk ini akan dianalisis menggunakan deskriptif kualitatif dengan cara penyajian data melalui beberapa pertanyaan sesuai dengan keadaan dan kebutuhan yang ada pada saat penelitian tanpa adanya perhitungan didalamnya, semua dijabarkan dalam bentuk deskriptif.

Angket validasi yang akan diberikan kepada ahli materi, bahasa, serta desain dan guru, pada penelitian dan pengembangan ini menggunakan skala Likert dan pengukuran yang merujuk pada buku karangan (Riduwan, 2016). Analisis kuantitatif merupakan pemberian soal yang akan di hasilkan skor dalam hal ini dapat dilihat pada rumus yang ada dibawah ini:

Rumus presentase yang digunakan, sebagai berikut:

$$
P=\frac{\Sigma \mathrm{x}}{\mathrm{s} \mathrm{xi}} \times 100 \%
$$

\section{Keterangan:}

P : Presentase

$\sum \mathrm{x} \quad$ : Jumlah keseluruhan jawaban responden dalam seluruh item

¿xi : Jumlah keseluruhan skor ideal

Untuk menentukan kriteria dalam menentukan hasil dari validasi, dirumuskan pada tabel berikut.

Tabel 1.Tingkat Kevalidan dan Revisi Produk 


\begin{tabular}{ll}
\hline Persentase (\%) & Kriteria Valid \\
\hline $76-100$ & Valid (tanpa revisi) \\
\hline $56-75$ & Cukup valid (tanpa revisi) \\
\hline $40-55$ & Kurang valid (revisi) \\
\hline $0-39$ & Tidak valid (revisi) \\
\hline & Sumber: (Listiawan, 2016)
\end{tabular}

\section{HASIL DAN PEMBAHASAN}

Pengembangan bahan ajar pada penelitian ini menggunakan model pengembangan ADDIE dengan tiga tahapan yaitu Analysis, Design dan Delevopment. Deskripsi data hasil penelitian dijelaskan sebagai berikut:

\section{Tahap Analysis (analisis)}

Pada tahap ini, langkah yang harus dilakukan oleh penulis yaitu mengumpulkan informasi terkait dengan permasalahan yang dihadapi dalam pembelajaran dengan cara melakukan wawancara kepada guru kelas III SD Negeri 29 Pekanbaru. Kemudian penulis akan mengidentifikasi permasalahan yang ada dan mengembangkan bahan ajar dengan berupa e-modul membaca pada pembelajaran tematik sebagai pemecahan masalahnya. Secara garis besar tahapan analisis yang dilakukan penulis adalah sebagai berikut:

\section{Analisis Pendidik}

Analisis pendidik bertujuan untuk mengetahui masalah apa saja yang dialami guru saat melakukan proses pembelajaran di kelas, sehingga diperlukan bahan ajar e-modul. Penelitian ini dikembangkan dari masalah yang muncul pada saat proses pembelajaran berlangsung. Berdasarkan hasil wawancara dengan guru, maka didapatkan informasi bahwa dalam kegiatan belajar mengajar lewat daring, tugas-tugas lebih banyak diberikan melalui whatsapp. Melalui whatsapp guru sering mengirimkan video-video pembelajaran mengenai materi yang diajarkan sehingga siswa lebih fokus belajar melalui handphone daripada membaca buku-buku pelajaran yang dipinjamkan sekolah. Siswa juga lebih banyak membaca materi-materi pembelajaran melalui internet pada handphone. Guru juga menyatakan bahwa terdapat beberapa kesulitan yang dialami selama pembelajaran, apalagi pada masa pandemi covid-19 seperti ini. Selama masa pandemi beliau menggunakan bahan ajar. Bahan ajar yang digunakan beliau seperti bahan ajar cetak dan non cetak.

Dalam proses pembelajaran bahan ajar yang digunakan beliau adalah dalam bentuk video. Selama proses pembelajaran terdapat beberapa kesulitan yang dialami oleh guru, yaitu 1) Dalam 
proses belajar berlangsung terbatasnya cara guru menerangkan, 2) Video yang dibuat kurang bervariasi sehingga siswa kurang tertarik, 3) Sekolah kurang memadai sarana dan prasarana

\section{Analisis Peserta Didik}

Sebagian besar banyak siswa mengalami masalah dalam mengikuti proses pembelajaran, seperti siswa tidak fokus dalam belajar, kemudian siswa tidak bersemangat dalam belajar. Maka dari itu dilakukan analisis untuk mengatasi kesulitan siswa saat mengikuti proses pembelajaran.

\section{Materi Pembelajaran}

Analisis yang dilakukan adalah analisis terkait kompetensi inti, kompetensi dasar (KD), dan indikator-indikator pencapaian kompetensi yang mengacu pada kurikulum 2013. Analisis ini akan menjadi dasar materi dalam pengembangan e-modul. Analisis kurikulum bertujuan untuk mengetahui cakupan materi, tujuan pembelajaran, dan pemilihan strategi yang sesuai sebagai landasan untuk mengembangkan e-modul yang diharapkan. Analisis yang dilakukan adalah menganalisis materi pada tema 2 subtema 3 kelas III SD.

\section{Tahap Design (Perancangan)}

E-modul yang dirancang disesuaikan dengan $\mathrm{KI}, \mathrm{KD}$, dan tujuanpembelajaran berdasarkan analisis yang telah dilakukan. E-modul membaca yang dirancang mendorong siswa untuk dapat meningkatkan kemampuan pemahaman akan bacaandan menambah pengetahuan tentang materi yang dipelajari. E-modul yang dirancang dilengkapi dengan warna-warna, gambar-gambar berwarna yang menarik bagi siswa.

E-modul membacadirancang pada microsoft office word kemudian diexport kebentuk PDF, dan selanjutnya di jadikan elektronik modul dengan bantuan website Flip Book Maker HTML.Tahapan perancangan e-modul membaca disesuaikan dengan isi e-modul. Berikut ini adalah bagian isi emodul.

\section{Cover (Sampul)}

Cover merupakan bagian sampul (depan dan belakang) darie-modulyang akan digunakanoleh siswadalam proses pembelajaran membaca. Pada cover depan dibuatkan judul e-modul, kelas, tema, subtema, dan nama penulis. Terlihat seperti pada gambar berikut. 


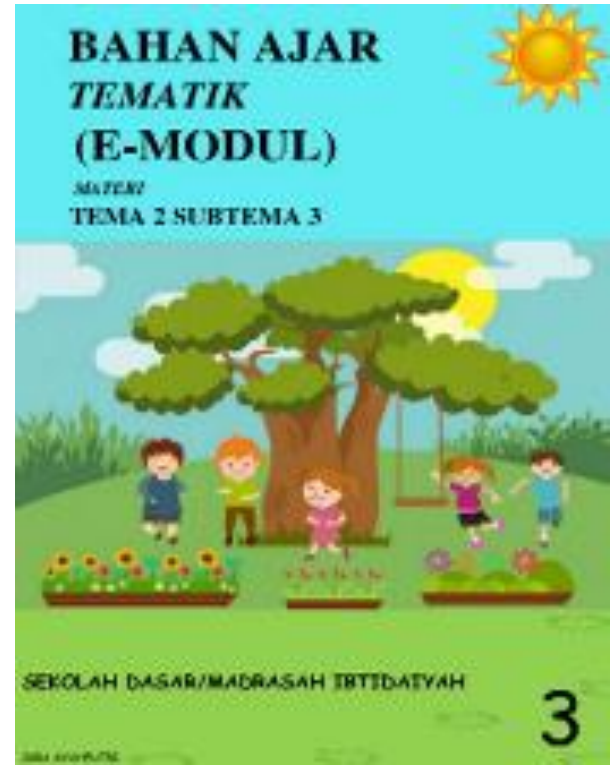

Gambar 1. Sampul depan

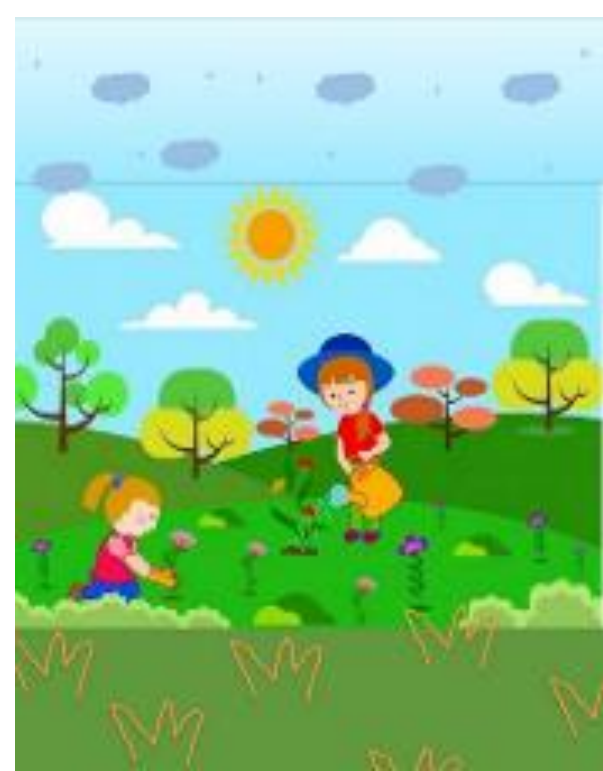

Gambar 2. Sampul belakang

\section{Kata Pengantar}

Kata pengantar berisi tujuan e-modul dan ucapan terimakasih atas selesainya e-modul ini, terlihat seperti pada gambar berikut.

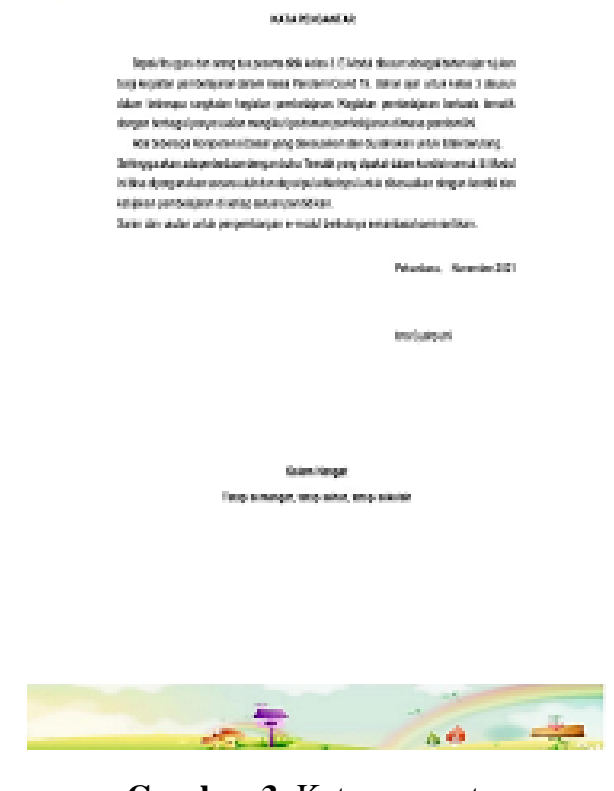

Gambar 3. Kata pengantar

\section{Cara Penggunaan E-Modul}

Halaman cara penggunaan e-modul berisi tentang hal-hal penting yang harus dipahami siswa sebelum menggunakan e-modul membacadalam proses pembelajaran. Terlihat seperti pada gambar berikut. 


\section{Cara Pensgunaan Modul}

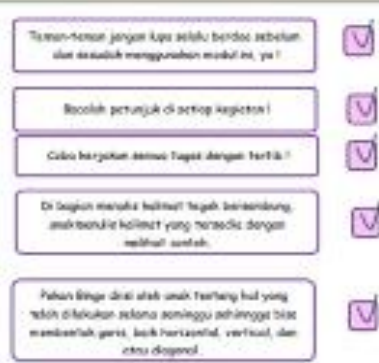

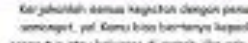

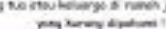

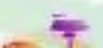

Gambar 4. Petunjuk e-modul

\section{Pembelajaran}

Pembelajaran merupakan bagian isi dari e-modul membaca dan merupakan bagian terpenting. Pada e-modul membaca terdapat enam pembelajaran yang dimulai dengan pembelajaran ke1hinggapembelajaran ke-6. Terlihat seperti pada gambar berikut.
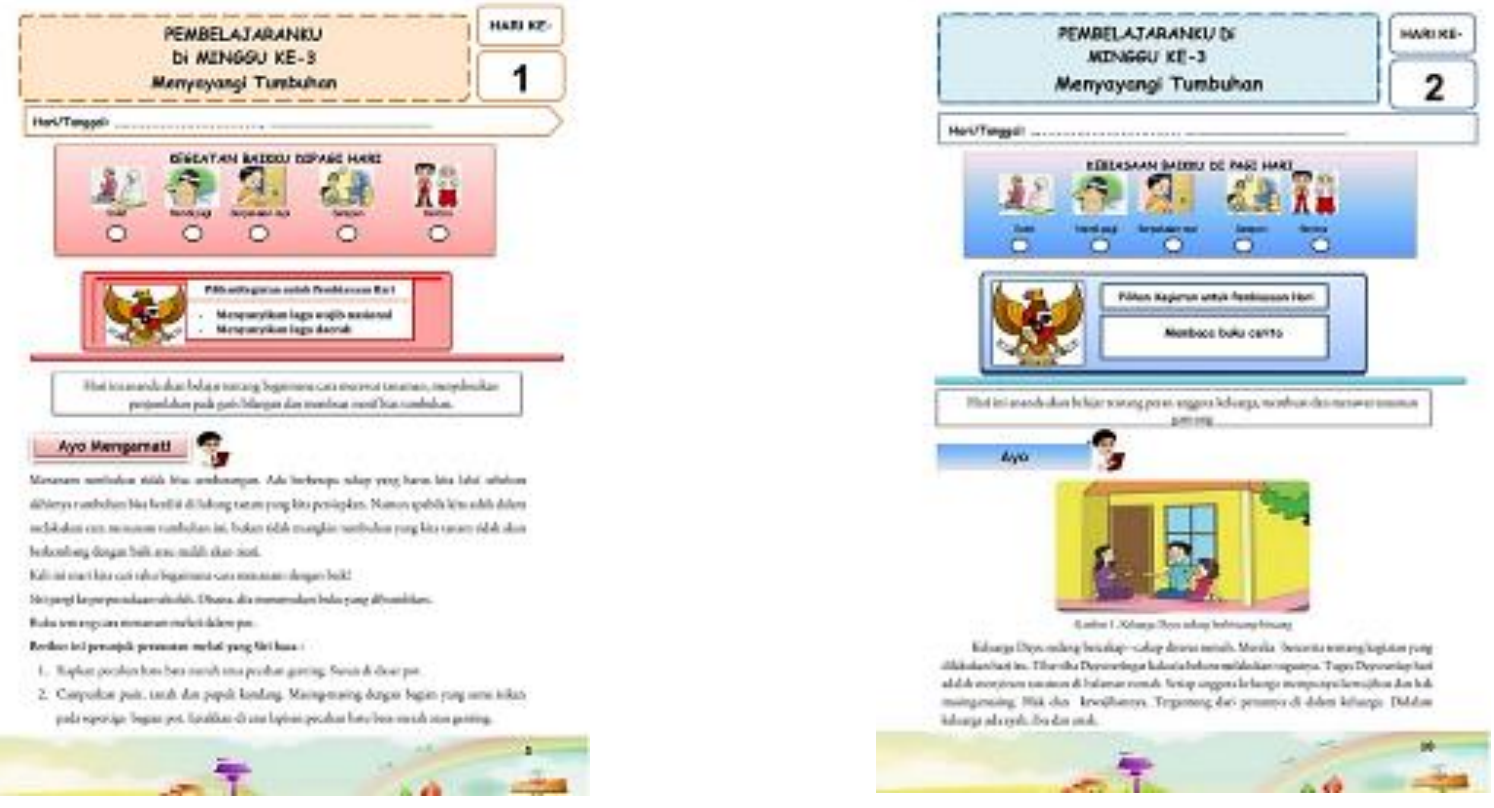

Gambar 5. Pembelajaran 1

Gambar 6. Pembelajaran 2 


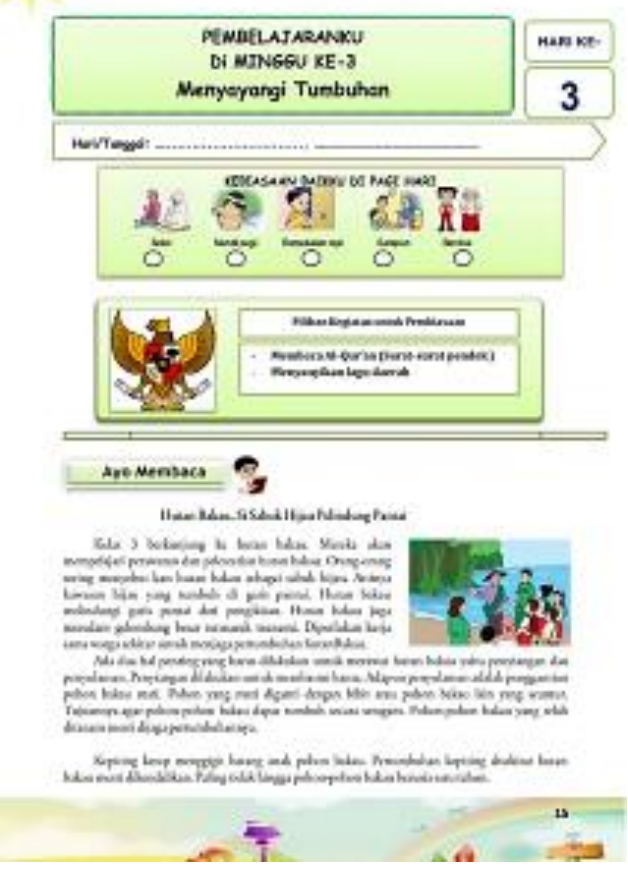

Gambar 7. Pembelajaran 3

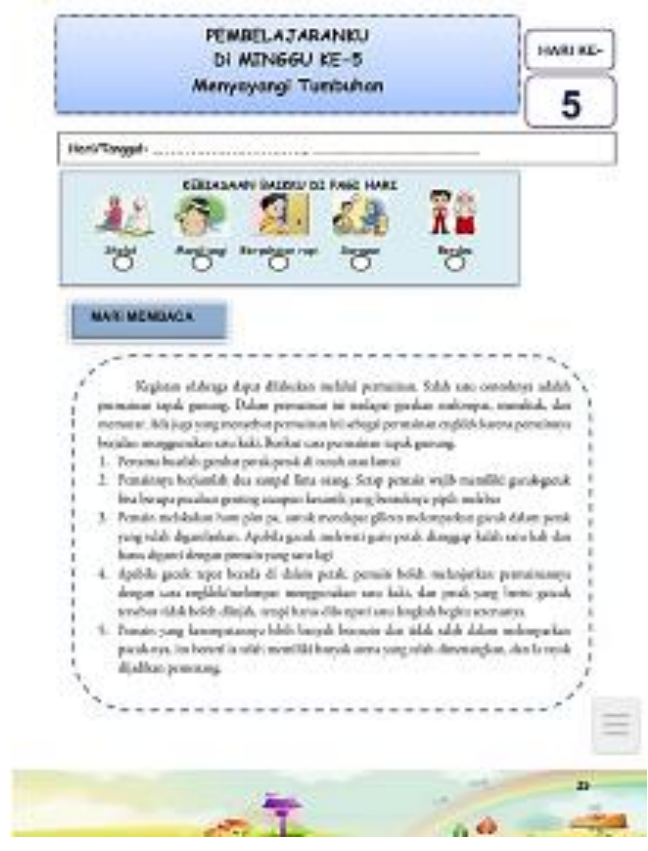

Gambar 9. Pembelajaran 5

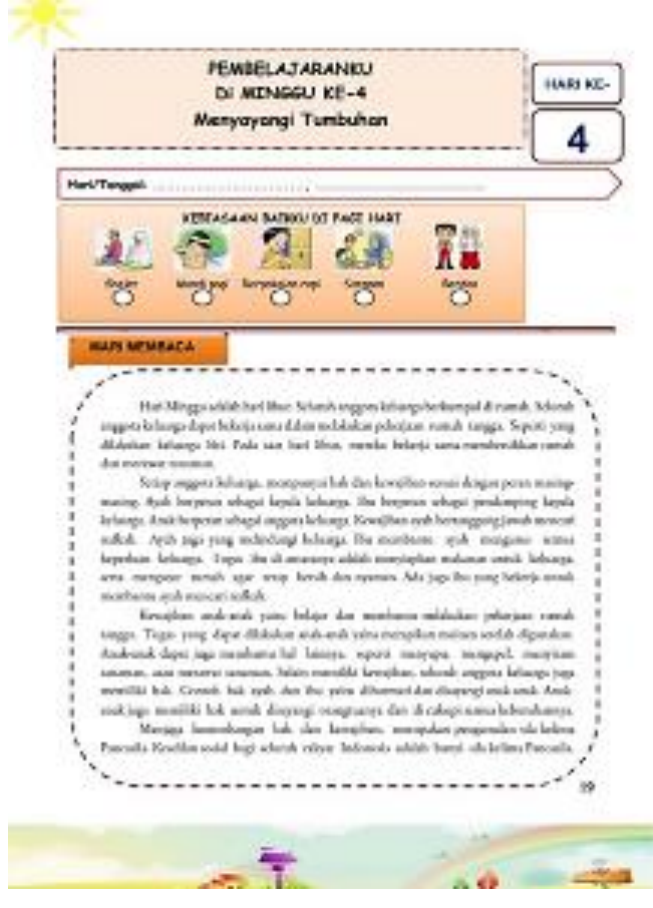

Gambar 8. Pembelajaran 4

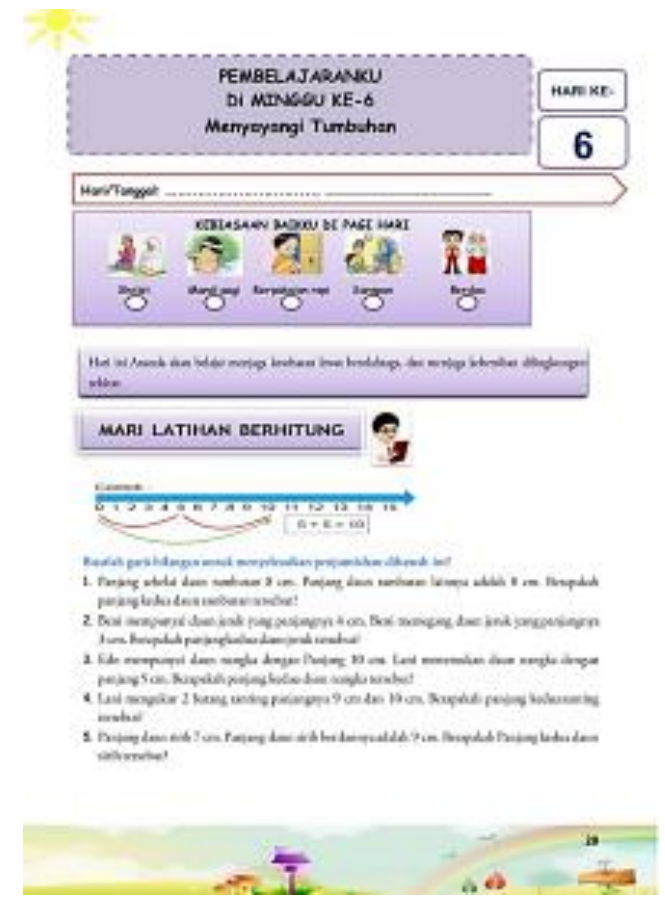

Gambar 10. Pembelajaran 6

\section{Evaluasi Akhir}

Evaluasi akhir berisi butiran-butiran soal yang akan dikerjakan siswa secara mandiri, terlihat pada gambar berikut. 


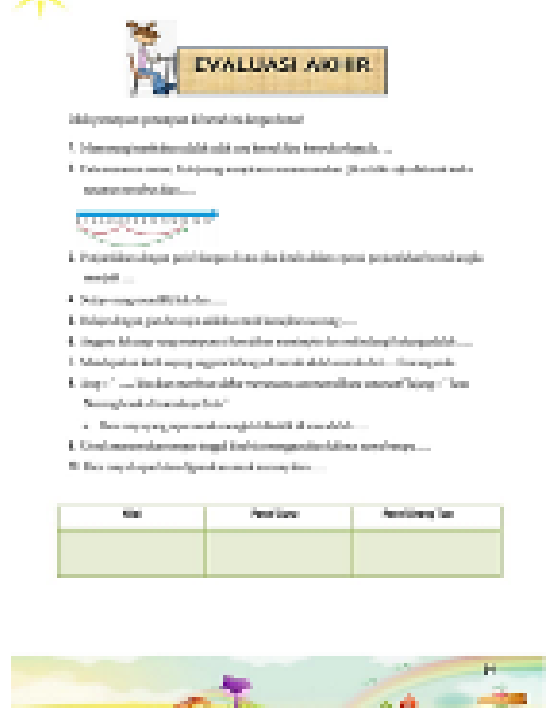

Gambar 11. Evaluasi akhir

\section{Kunci Jawaban}

Tujuan pembuatan kunci jawaban adalah untuk mengetahui kebenaran jawaban dari pertanyaan yang dijawab siswa. Berikut ini contoh tampilan kunci jawaban.

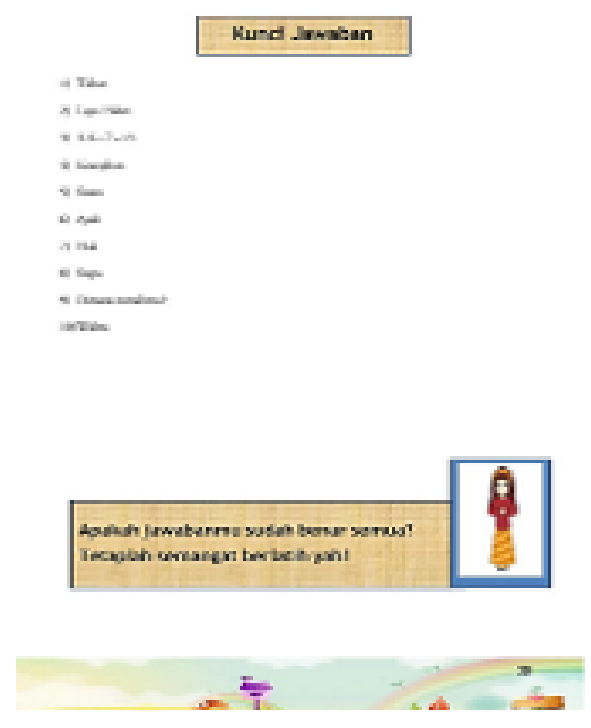

Gambar 12. Kunci jawaban

\section{Tahap Develop (Pengembangan)}

Tahap pengembangan bertujuan untuk menghasilkan e-modul membaca yang valid sehingga layak digunakan dalam proses pembelajaran. Berdasarkan validasi produk ini dilakukan dengan cara menghadirkan beberapa pakar atau tenaga ahli yang sudah berpengalaman untuk menilai bahan ajar berupa e-modul pada tema 2 subtema 3 yang telah dibuat oleh peneliti. Peneliti melakukan penilaian dengan dua orang ahli media, dua orang ahli materi, dan dua orang ahli bahasa.

Validasi desain dilakukan dengan dua orang ahli dalam menilai desain. Perhitungan persentase pada 
validasi pertama diperoleh rata-rata skor sebesar 84,62\% (Valid). Setelah bahan ajar berupa e-modul direvisi berdasarkan saran dan komentar yang diperoleh dari hasil validasi pertama, maka selanjutnya akan dilakukan validasi kedua dengan memperoleh rata-rata skor sebesar 100\% (Valid). Selanjutnya diperoleh rata-rata akhir uji validasi desain sebesar 92,31 (Valid). Hasil perhitungan validasi pertama dan kedua e-modul tematik sudah sangat layak digunakan untuk pembelajaran, semua data dari hasil review, penilaian, dan diskusi dengan ahli desain dijadikan bahan pertimbangan penyempurnaan komponen e-modul tematik sebelum digunakan oleh siswa.

Tabel 2. Hasil Uji Validasi Desain

\begin{tabular}{lll}
\hline \multirow{2}{*}{ Validator } & Persentase & \\
\cline { 2 - 3 } & Validasi Tahap Pertama & Validasi Tahap Kedua \\
\hline Validator 1 & $94,23 \%$ & $100 \%$ \\
Validator 2 & $75 \%$ & $100 \%$ \\
\hline \multirow{2}{*}{ Rata-Rata } & $\mathbf{8 4 , 6 2 \%}$ & $\mathbf{1 0 0 \%}$ \\
\hline Kategori & $\mathbf{9 2 , 3 1 \%}$ & \\
\hline
\end{tabular}

Validasi materi dilakukan dengan dua orang ahli dalam menilai isi materi. Perhitungan persentase pada validasi pertama diperoleh rata-rata skor sebesar 80,55\% (Valid). Setelah e-modul tematik direvisi berdasarkan saran dan komentar yang diperoleh dari hasil validasi pertama, maka selanjutnya akan dilakukan validasi kedua dengan memperoleh rata-rata skor sebesar 94,44\% (Valid). Selanjutnya diperoleh rata-rata akhir uji validasi materi sebesar 87,49\% (Valid). Selanjutnya diperoleh rata-rata akhir uji validasi materi sebesar 87,49 (Valid). Hasil perhitungan validasi pertama dan kedua e-modul tematik sudah sangat layak digunakan untuk pembelajaran, semua data dari hasil review, penilaian, dan diskusi dengan ahli materi dijadikan bahan pertimbangan penyempurnaan komponen e-modul tematik sebelum digunakan oleh siswa.

Tabel 3. Hasil Uji Validasi Materi

\begin{tabular}{lll}
\hline \multirow{2}{*}{ Validator } & Persentase & \\
\cline { 2 - 3 } & Validasi Tahap Pertama & Validasi Tahap Kedua \\
\hline Validator 3 & $77,78 \%$ & $94,44 \%$ \\
Validator 4 & $83,33 \%$ & $94,44 \%$ \\
\hline \multirow{2}{*}{ Rata-Rata } & $\mathbf{8 0 , 5 5 \%}$ & $\mathbf{9 4 , 4 4 \%}$ \\
\hline Kategori & $\mathbf{8 7 , 4 9 \%}$ & \\
\hline & Valid & \\
\hline
\end{tabular}

Validasi bahasa dilakukan dengan dua orang ahli dalam menilai pedoman umum ejaan bahasa 


\section{PENGEMBANGAN E-MODUL MEMBACA SISWA KELAS 3 SDN 029 PEKANBARU \\ Isra Syahputri, Febrina Dafit}

indonesia (PUEBI). Perhitungan persentase pada validasi pertama diperoleh rata-rata skor sebesar 73,44\% (Valid). Setelah e-modul tematik direvisi berdasarkan saran dan komentar yang diperoleh dari hasil validasi pertama, maka selanjutnya akan dilakukan validasi kedua dengan memperoleh ratarata skor sebesar 90,63\% (Valid). Selanjutnya diperoleh rata-rata akhir uji validasi bahasa sebesar 82,04 (Valid). Hasil perhitungan validasi pertama dan kedua e-modul tematik sudah sangat layak digunakan untuk pembelajaran, semua data dari hasil review, penilaian, dan diskusi dengan ahli desain dijadikan bahan pertimbangan penyempurnaan komponen e-modul tematik sebelum digunakan oleh siswa.

Tabel 4. Hasil Uji Validasi Bahasa

\begin{tabular}{lll}
\hline \multirow{2}{*}{ Validator } & \multicolumn{2}{l}{ Persentase } \\
\cline { 2 - 3 } & Validasi Tahap Pertama & Validasi Tahap Kedua \\
\hline Validator 5 & $84,38 \%$ & $90.63 \%$ \\
Validator 6 & $62,5 \%$ & $90,63 \%$ \\
\hline \multirow{2}{*}{ Rata-Rata } & $\mathbf{7 3 , 4 4 \%}$ & $\mathbf{9 0 , 6 3 \%}$ \\
\hline Kategori & $\mathbf{8 2 , 0 4 \%}$ & \\
\hline
\end{tabular}

Tabel 5. Rata-Rata Nilai Validasi

\begin{tabular}{lllll}
\hline No & Ahli & Rata-Rata & Nilai Akhir & Kategori \\
\hline \multirow{2}{*}{1} & Validator Desain Pertama & $97,12 \%$ & $92,31 \%$ & Valid \\
& Validator Desain Kedua & $87,5 \%$ & Valid \\
\hline \multirow{2}{*}{2} & Validator Materi Pertama & $86,11 \%$ & $87,49 \%$ & Valid \\
& Validator Materi Kedua & $88,86 \%$ & & Valid \\
3 & Validator Bahasa Pertama & $87,51 \%$ & $82,04 \%$ & Valid \\
\hline Rata-Rata & $76,56 \%$ & & Valid
\end{tabular}

(Sumber: Data Olahan Peneliti)

Berdasarkan tabel 3.4 diatas ini, nilai yang diperoleh dari validasi ahli desain menperoleh rata-rata sebesar 92,31\% dengan kategori "Valid", dan ahli materi memperoleh rata-rata sebesar 87,49\% dengan kategori "Valid", dan ahli bahasa memperoleh rata-rata sebesar 82,04\% dengan kategori "Valid", sehingga nilai rata-rata yang diperoleh dari pengembangan e-modul tematik ini sebesar 87,28\% dengan kategori "Valid".

Setelah dilakukan validasi oleh ahli desain, ahli materi, dan ahli bahasa selanjutnya dilakukan responguru dan peserta didik yang terdiri dari dua orang guru dan enam orang peserta didik kelas III. Adapun respon yang diberikan oleh guru dan peserta didik dapat dilihat pada tabel 3.5 dan 3.6 diantaranya yaitu sebagai berikut. 
Tabel 6. Respon Wali Kelas III

\begin{tabular}{|c|c|c|c|}
\hline No & AspekPenilaian & GuruI & Guru II \\
\hline 1 & PengorganisasianMateri & $96 \%$ & $91,4 \%$ \\
\hline 2 & EvaluasidanLatihan & $96 \%$ & $96 \%$ \\
\hline 3 & Produke-modul & $92 \%$ & $91,4 \%$ \\
\hline 4 & Efek BagiPengguna & $86,6 \%$ & $93,3 \%$ \\
\hline \multirow{2}{*}{\multicolumn{2}{|c|}{ Rata-Rata }} & $92,65 \%$ & $93,01 \%$ \\
\hline & & \multicolumn{2}{|c|}{$\mathbf{9 2 , 8 3 \%}$} \\
\hline
\end{tabular}

\section{Kriteria}

Sangat Menarik

Dari tabel 3.5rata-rata yang diberikan guru kelas IIIsebesar 92,83\% sehingga memperolehkategori“Sangat Menarik”. Sejalan dengan pendapat guru yang menyampaikan bahwa e-modul inimenarik perhatian peserta didik untuk belajar dan tingkat keinginan peserta didik belajar meningkat. Peneliti juga melakukan penilaian untuk mendapatkan respon peserta didik terhadap e-modul ini. Adapun hasil responyang diberikanoleh peserta didik,terdapatpadatabel3.6sebagaiberikut.

Tabel 7. Respon Peserta Didik Kelas III

\begin{tabular}{llllll}
\hline No & Nama & Jumlah & $\begin{array}{l}\text { Skor } \\
\text { Maksimal }\end{array}$ & Presentasi & Kriteria \\
\hline 1 & FAH & 8 & 10 & $80 \%$ & Sangat Menarik \\
2 & IA & 9 & 10 & $90 \%$ & Menarik \\
3 & MS & 8 & 10 & $80 \%$ & Sangat Menarik \\
4 & REP & 9 & 10 & $90 \%$ & Sangat Menarik \\
5 & RSA & 10 & 10 & $100 \%$ & Sangat Menarik \\
6 & FH & 9 & 10 & $90 \%$ & Sangat Menarik \\
\hline & Jumlah Skor & $\mathbf{5 3}$ & $\mathbf{6 0}$ & $\mathbf{8 8 , 3 3 \%}$ & Sangat Menarik \\
\hline
\end{tabular}

Berdasarkan tabel 3.6 hasil uji coba lapangan skala terbatas yang melibatkan 6 orang peserta didik menunjukkan hasil jumlah skor 53 dari skor maksimal pernyataan adalah 60. Selanjutnya diketahui bahwa tanggapan peserta didik dari uji coba skala terbatas ini diperoleh rata-rata presentase penilaian sebesar 88,33\% dengan kriteria "Sangat Menarik".

\section{KESIMPULAN}

Berdasarkan rumusan masalah serta analisis data penelitian dan pembahasan, maka peneliti menyimpulkan bahwa dari pengujian validasi yang dilakukan oleh ahli desain dengan rata-rata persetase $92,31 \%$ dalam kategori valid, dari penguji validasi yang dilakukan oleh ahli materi pembelajaran tematik dengan rata-rata persentase sebanyak 87,49\% dalam kategori valid dan terakhir penguji validasi oleh ahli bahasa dengan rata-rata persentase sebanyak 82,04\% dalam kategori valid. Selanjutnya diperoleh rata-rata akhir pengujian validasi E-modul sebesar $87,28 \%$ dalam kategori 
valid. Kemudian berdasarkan analisis dari angket respon guru kelas III terhadap e-modul membaca mendapatkan respon positif yang memperoleh rata-rata sebesar 92,83\% yang menunjukkan kategori "Sangat Menarik". Analisis dari angket respon peserta didik terhadap e-modul membaca pada pembelajaran tematik mendapatkan respon positif yang memperoleh rata-rata sebesar 83,33\% yang menunjukan kategori "Sangat Menarik". Jadi dapat ditarik kesimpulan bahwa bahan ajar berupa emodul membaca dalam pembelajaran tematik sudah sesuai dan layak digunakan untuk kegiatan pembelajaran.

\section{DAFTAR PUSTAKA}

Budiarti, W. N., \& Haryanto. (2016). Pengembangan media komik untuk meningkatkan motivasi belajar dan keterampilan membaca Pemahaman siswa kelas IV. Jurnal Prima Edukasia,4 (2),hlm.233-242.

Desyandri, D., Muhammadi, M., Mansurdin, M., \& Fahmi, R. (2019). Development of integrated thematic teaching material used discovery learning model in grade $\mathrm{V}$ elementary school. Jurnal Konseling Dan Pendidikan, 7(1), 16. https://doi.org/10.29210/129400

Hanafi. (2017). KONSEP PENELITIAN R \& D DALAM BIDANG PENDIDIKAN. Saintifika Islamica: Jurnal Kajian Keislaman, 4(1989), 129-150.

Herawati, N. S., \& Muhtadi, A. (2018). Developing Interactive Chemistry E-Modul For The Second Grade Students of Senior High School. Jurnal Inovasi Teknologi Pendidikan, 5(2), 180-191.

Lestari, D. (2017). Pengembangan Bahan Ajar Tematik Untuk Siswa Kelas Iv. Direktorat UPI Bandung, $2(1)$ 1489-1497. http://file.upi.edu/Direktori/FIP/JUR._KURIKULUM_DAN_TEK._PENDIDIKAN/1946012 91981012-PERMASIH/PENGEMBANGAN_BAHAN_AJAR.pdf

Listiawan, T. (2016). Pengembangan learning management system ( $\mathrm{lms}$ ) di program studi pendidikan matematika stkip pgri tulungagung. Jurnal Ilmiah Pendidikan Informatika, 1(1), 14-22.

Qondias, D., Anu, E. L., Niftalia, I., Pendidikan, S., \& Sekolah, G. (2016). PENGEMBANGAN MEDIA PEMBELAJARAN TEMATIK BERBASIS MIND MAPING SD KABUPATEN NGADA FLORES. Jurnal Pendidikan Indonesia |, 5(2), 176-182.

Riduwan. 2016. Dasar-dasar Statistika. Bandung: Alfabeta

Rif'ati, D. H. (2015). DEVELOPING OF ELECTRONIC TEACHING MATERIAL BASED ON MOBILE LEARNING IN THE WAVE SUBJECTS. Jurnal Pendidikan Fisika Indonesia, 11(2), 65-76. https://doi.org/10.15294/jpfi 
Setiawan, W., \& Andika Sari, V. T. (2018). Pengembangan Bahan Ajar Konsep Diferensial Berbasis Konflik Kognitif. Jurnal Elemen, 4(2), 204. https://doi.org/10.29408/jel.v4i2.511

Suratmi, S., Laihat, L., \& Santri, D. J. (2018). Development of Teaching Materials Based on Local Excellences of South Sumatera for Science Learning in Elementary School. Jurnal Penelitian Dan Pembelajaran IPA, 4(1), 35. https://doi.org/10.30870/jppi.v4i1.3336

Tristiantari, N. K. D., \& Sumantri, I. M. (2016). Model Pembelajaran Cooperatif Integrated Reading Composition Berpola Lesson Study Meningkatkan Keterampilan Membaca Dan Menulis. JPI (Jurnal Pendidikan Indonesia), 5(2), 203. https://doi.org/10.23887/jpi-undiksha.v5i2.8493 
PENGEMBANGAN E-MODUL MEMBACA SISWA KELAS 3 SDN 029 PEKANBARU Isra Syahputri, Febrina Dafit 